\title{
LONG-TERM MORTALITY AFTER PRIMARY PCI FOR STEMI IN PATIENTS WITH INSULIN-DEPENDENT DIABETES MELLITUS
}

\author{
Petar Zlatanović ${ }^{1}$, Stefan Zaharijev ${ }^{1}$, Goran Stanković ${ }^{2}$ \\ ${ }^{1}$ Faculty of Medicine, University of Belgrade, Serbia \\ ${ }^{2}$ Mentor: Cardiology Clinic, Clinical Center of Serbia \\ Contact e-mail: petarzlatanovic@yahoo.com
}

Sažetak

Uvod: Primarna PCI (pPCI) je zlatni standard u lečenju bolesnika sa akutnim infarktom miokarda (AIM) sa ST elevacijom (STEMI).

Cilj: Cilj ove studije je da ispita uticaj dijabetičnog statusa na prijemu na petogodišnje preživljavanje kod pacijenata sa STEMI lečenih pPCI.

Materijal i metode: Konsekutivni podaci za 2087 pacijenata primljenih u periodu od 1. januara 2009. do 31. decembra 2010. godine sa dijagnozom akutnog STEMI su prikupljeni iz elektronske baze podataka sale za kateterizaciju klinike za kardiologiju KCS. Pacijenti su podeljeni u 3 grupe: bez diabetes mellitusa (DM), bolesnici sa DM koji nisu na insulinskoj terapiji - NIDDM (non-insulin dependent diabetes mellitus), bolesnici sa DM koji su na insulinskoj terapiji - IDDM (insulin dependent diabetes mellitus).

Rezultat: 1664 (79,7\%) nije imalo DM, 98 (4,7\%) je imalo IDDM, a $325(15,6 \%)$ je imalo NIDDM. Postojala je statistički značajna razlika u stopi mortaliteta između tri grupe nakon 30 dana, godinu dana i 5 godina od intervencije, a najviša stopa je zabeležna kod IDDM bolesnika, zatim u grupi NIDDM i najniža kod bolesnika bez DM $(15,3 \%$ vs $8,3 \%$ vs $5,9 \%, \mathrm{p}<0,001$ nakon 30 dana; $21,4 \%$ vs $15,4 \%$ vs $10,9 \%, p<0,001$ nakon godinu dana; $32,7 \%$ vs $24,3 \%$ vs $18,0 \%$ p $<0,001$ nakon 5 godina). Takođe, postojala je visoko statistički značajna razlika u stopi petogodišnjeg mortaliteta između pacijenata sa i bez DM $(26,2 \%$ vs $17,6 \%$, p < 0,001). IDDM je bio nezavisan prediktor petogodišnjeg mortaliteta $(\mathrm{HR}=1,58$, 95\% CI 1,07-2,32, $\mathrm{p}=0,02)$, dok NIDDM nije dostigao statističku značajnost $(\mathrm{HR}=1,24,95 \%$ CI $0,95-1,63, \mathrm{p}=$ $0,12)$.

Zaključak: Kod bolesnika sa DM postoji povišen rizik od smrtnosti u kratkoročnom i dugoročnom praćenju nakon pPCI. Insulin-zavisan diabetes je nezavisan prediktor višeg petogodišnjeg mortliteta.

Ključne reči: DM, IDDM, NIDDM, STEMI, pPCI
Abstract

Introduction: Primary PCI (pPCI) is the gold standard in the treatment of patients with acute myocardial infarction (AMI) with ST elevation (STEMI).

Aim: The purpose of this study is to evaluate the influence of diabetic status upon arrival at five year survival in patients with STEMI that were treated with pPCI.

Material and methods: Consecutive data for 2087 patients admitted in the period from $1^{\text {st }}$ of January 2009. to $31^{\text {st }}$ of December 2010. with diagnosis of acute STEMI were collected from catheterisation laboratory cardiology clinic CCS electronic database. Patients were divided into 3 groups: those without diabetes mellitus (DM), IDDM (insulin dependent diabetes mellitus), NIDDM (non-insulin dependent diabetes mellitus).

Results: 1664 patients (79.7\%) did not have DM, 98 (4.7\%) had IDDM and 325 (15.6\%) had NIDDM. There was a statistically significant difference in mortality rate among three groups after 30 days, one year and five years after intervention, and the highest rates were recorded at the IDDM patients, then at the NIDDM and the lowest in patients without DM $(15.3 \%$ vs $8.3 \%$ vs $5.9 \%, \mathrm{p}<0.001$ after 30 days; $21.4 \%$ vs $15.4 \%$ vs $10.9 \%$, $\mathrm{p}<0.001$ after one year and $32.7 \%$ vs $24.3 \%$ vs $18 \%$, $\mathrm{p}<0.001$ after 5 years). Also, there was a highly statistically significant difference in five-year mortality rate between patients with and without DM (26.2\% vs $17.6 \%$, $\mathrm{p}<0.001)$. IDDM was a independent factor when it comes to predicting five-year mortality ( $\mathrm{HR}=1.58,95 \%$ CI $1.07-2.32, \mathrm{p}=0.02)$ whereas NIDDM was not $(\mathrm{HR}=$ $1.24,95 \%$ CI $0.95-1.63, \mathrm{p}=0.12$ ).

Conclusion: Diabetic patients had an increased risk of mortality in the short and long-term follow-up after pPCI. Insulin-dependent was a single predicting factor after five year follow-up.

Key words: DM, IDDM, NIDDM, STEMI, pPCI 


\section{Introduction}

Acute myocardial infarction (AMI) is the leading cause of morbidity and mortality in the world. According to the Institute of Public Health of Serbia "Dr Milan Jovanovic Batut" the most common cause of death are cardiovascular diseases (CVD) in $52.3 \%$ of cases, with a high proportion of ischemic heart disease - 18.5\% [1].

Prompt implementation of thrombolytic therapy achieves reperfusion in a greater percentage of cases when compared with spontaneous reperfusion without therapy (50-60\% vs. 15\%). Percutaneous coronary intervention (PCI) achieves reperfusion up to $95 \%$ and therefore there is an obvious benefit of this procedure in comparison to other methods [2]. Primary angioplasty of acute myocardial infarction, or primary PCI (pPCI) are the terms relating to the use of balloon angioplasty, usually with stent implantation, in opening blocked coronary arteries instead of thrombolytic therapy. It is the gold standard in the treatment of patients with acute myocardial infarction with ST segment elevation myocardial infarction (STEMI).

Diabetes mellitus (DM) is present in $20-30 \%$ of patients with AMI (3). Although pPCI significantly reduced morbidity and mortality after STEMI compared with thrombolytic therapy, patients with STEMI who have DM continue to have a worse prognosis than patients without DM.

Patients with DM can be divided into 3 groups: those who are treated with insulin (IDDM - insulin dependent diabetes mellitus) and in patients who are not treated with insulin - NIDDM (non-insulin dependent diabetes mellitus). Earlier studies have shown that patients with STEMI and IDDM have an increased risk of major cardiac events adverse (MACE) [3].

The main objective of this study was to evaluate the influence of diabetes, as well as the influence of the mode of treatment of diabetes (insulin vs. oral hypoglycemic agents) at the mortality rate after 30 days, 1 and 5 years in patients with STEMI treated pPCI.

\section{Materials and methods}

Consecutive data for 2087 patients admitted during the period from $1^{\text {st }}$ of January 2009 to $31^{\text {st }}$ of December 2010 diagnosed with acute STEMI were collected from electronic databases catheterization at the Clinic for Cardiology CCS. The diagnosis of acute STEMI was made when the patients had symptoms for AIM accompanied with the signs of elevation $>1 \mathrm{~mm}(0.1 \mathrm{mV})$ in $\geq$ 2 adjacent ECG leads with increased cardiospecific enzymes. Patients were emergently transported to the heart catheterization lab where they underwent the urgent coronary angiography. PCI was performed by using standard techniques if the anatomy of the coronary circulation was adequate. All procedural decisions, including the selection of the number, type and method of implantation and application of support pharmacotherapy, such as inhibitors of glycoprotein IIb / IIIa inhibitors, aspirin and PY12 receptor antagonists were done by operator in accordance with current guidelines (4).

Upon arrival, operator noted the presence or absence of DM, and the way of glucoregulation (insulin vs. oral hypoglycemic agents). Based on medical history, laboratory data and insight into medical records, patients were divided into 3 groups: without diabetes mellitus $(\mathrm{DM})$, patients with DM who are not on insulin therapy - NIDDM (non-insulin dependent diabetes mellitus), patients with DM who are insulin therapy - IDDM (insulin dependent diabetes mellitus). All patients to whom primary PCI was performed were prospectively followed. Baseline clinical data on admission, angiographical and procedural information were entered by qualified personnel and interventional cardiologists in the electronic database. Pieces of information about follow-up were obtained after one month, one year and five years after the intervention was done.

Baseline characteristics that were monitored are: gender, age, previous AMI, previous stroke, previous PCI, previous coronary artery bypass graft (CABG), hyperlipoproteinemia (HLP), smoking, previous atrial fibrillation (AF), renal failure and body mass index (BMI). The difference in baseline characteristics between the groups was tested by using $\chi^{2}$ test. Statistical significance was defined as $\mathrm{p}$-value $<0.05$. Nonparametric test (Kruskal-Wallis) was used to calculate the statistically significant differences between groups for body mass index (BMI) and age. Cumulative mortality rates were estimated using Kaplan-Meier method and log-rank test was shown a statistically significant difference in mortality between the groups. Cox regression analysis (Cox regression hazard ratio) was used for multivariate analysis of survival between groups adjusted on the basis of the basic characteristics. All analysis were conducted using statistical software SPSS version 20 (SPSS Inc., Chicago, IL, USA).

\section{Results}

The cohort study consisted of 2087 STEMI patients. 423 patients $(20.26 \%)$ had a DM, of which 98 (4.7\%) with IDDM, and 325 (15.57\%) with NIDDM. Table 1 shows the baseline characteristics of 423 STEMI patients with DM, 1664 without DM. There was a statistically significant difference $(\mathrm{p}<0.0001)$ between patients with IDDM, NIDDM and patients without DM in terms 
of gender, BMI, prevalence of cerebrovascular insult, previous renal insufficiency, previous atrial fibrillation, percent of the female population and prevalence of smoking.
Table 2 shows mortality after 30 days of pPCI after one and five years of pPCI.

Table 1. Baseline characteristics in three groups (patients without DM, with NIDDM and with IDDM)

\begin{tabular}{lcccc} 
Basic characteristics & $\begin{array}{c}\text { patients with IDDM } \\
\mathrm{n=} 98(4,7 \%)\end{array}$ & $\begin{array}{c}\text { patients with NIDDM } \\
\mathrm{n}=325(15,57 \%)\end{array}$ & $\begin{array}{c}\text { patients without DM } \\
\mathrm{n}=1664(79,74 \%)\end{array}$ & p-value \\
\hline Females \% & $41.8 \%$ & $37.2 \%$ & $27 \%$ & 0.0001 \\
Previous AIM \% & $19.4 \%$ & $16.4 \%$ & $14 \%$ & 0.208 \\
Previous CVI & $9.2 \%$ & $11.1 \%$ & $4.8 \%$ & 0.0001 \\
Previous PCI & $3.1 \%$ & $8.6 \%$ & $6.8 \%$ & 0.15 \\
Previous CABG & $1 \%$ & $2.8 \%$ & $1.4 \%$ & 0.164 \\
HLP & $60.2 \%$ & $64.9 \%$ & $59.2 \%$ & 0.156 \\
Smoking & $27.6 \%$ & $36.3 \%$ & $56.4 \%$ & 0.0001 \\
Previous AF & $1 \%$ & $3.2 \%$ & $1.2 \%$ & 0.032 \\
Renal insufficiency & $13.3 \%$ & $3.4 \%$ & $2.5 \%$ & 0.0001 \\
Age (IQR) & $64,02(51,02-77,02)$ & $63,41(47,41-79,41)$ & $59,11(42,11-76,11)$ & 0.0001 \\
BMI (IQR) & $28,18(22,71-33,65)$ & $28,64(23,33-33,95)$ & $26,87(21,86-31,88)$ & 0.0001 \\
AIM- acute myocardial infarction, CVI- cerebrovascular insult, pPCI- primary percutaneous coronary \\
intervention, CABG- coronary artery bypass graft, HLP- hyperlipoproteinemia, AF- atrial fibrillation, BMI- body \\
mass index, CI- confidence interval, IQR- interquartile range & &
\end{tabular}

Table 2. Mortality after 30 days, one and five years

\begin{tabular}{rcccc} 
Time of death & patients with IDDM & patients with NIDDM & patients without DM & p-vrednost \\
\hline 30 days after $\mathrm{p} P C I$ & $15.3 \%$ & $8.3 \%$ & $5.9 \%$ & 0.0001 \\
1 years after $\mathrm{p} P C I$ & $21.4 \%$ & $15.4 \%$ & $10.9 \%$ & 0.0001 \\
5 years after $P C I$ & $32.7 \%$ & $24.3 \%$ & $18 \%$ & 0.0001
\end{tabular}

There was a highly statistically significant difference between the three groups 30 days (IDDM NIDDM $15.3 \%$ vs $8.3 \%$ vs $5.9 \%$ without $\mathrm{DM}, \mathrm{p}<0.001$ ), after one year (IDDM $21.4 \%$ vs NIDDM $15.4 \%$ vs without DM
$10.9 \%, \mathrm{p}<0.001)$ and after five years of pPCI (IDDM $32.7 \%$ vs NIDDM $24.3 \%$ vs without DM $18 \%$, p < 0.001 ) (Graph 1).

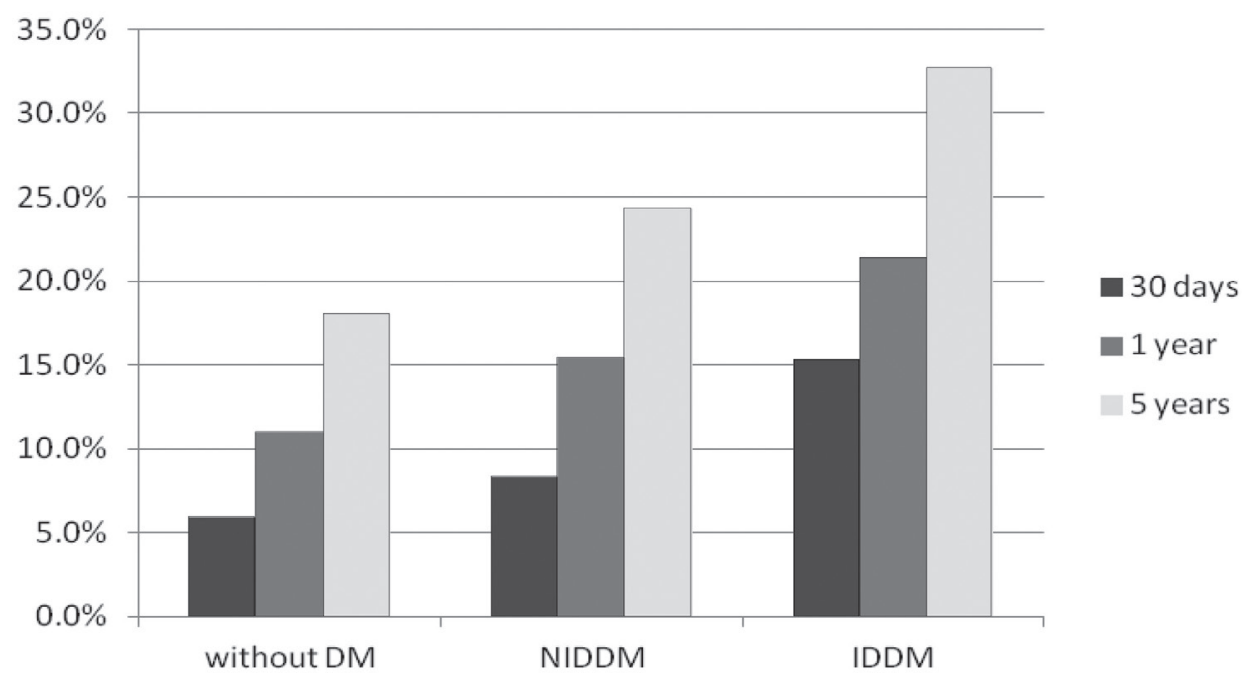

Graph 1. Kaplan-Meier survival curve for all three groups of patients 
Kaplan-Meier survival curve after five-year follow-up is shown in Graph 2 . After five years there was a statistically significant difference between the groups (Log-rank test, X2 $=20.08, \mathrm{p}<0.0001$ ), also there was statistically significant difference in mortality rates between patients with and without DM (26.2\% vs $17.6 \%$; $\mathrm{p}<0.001)$.

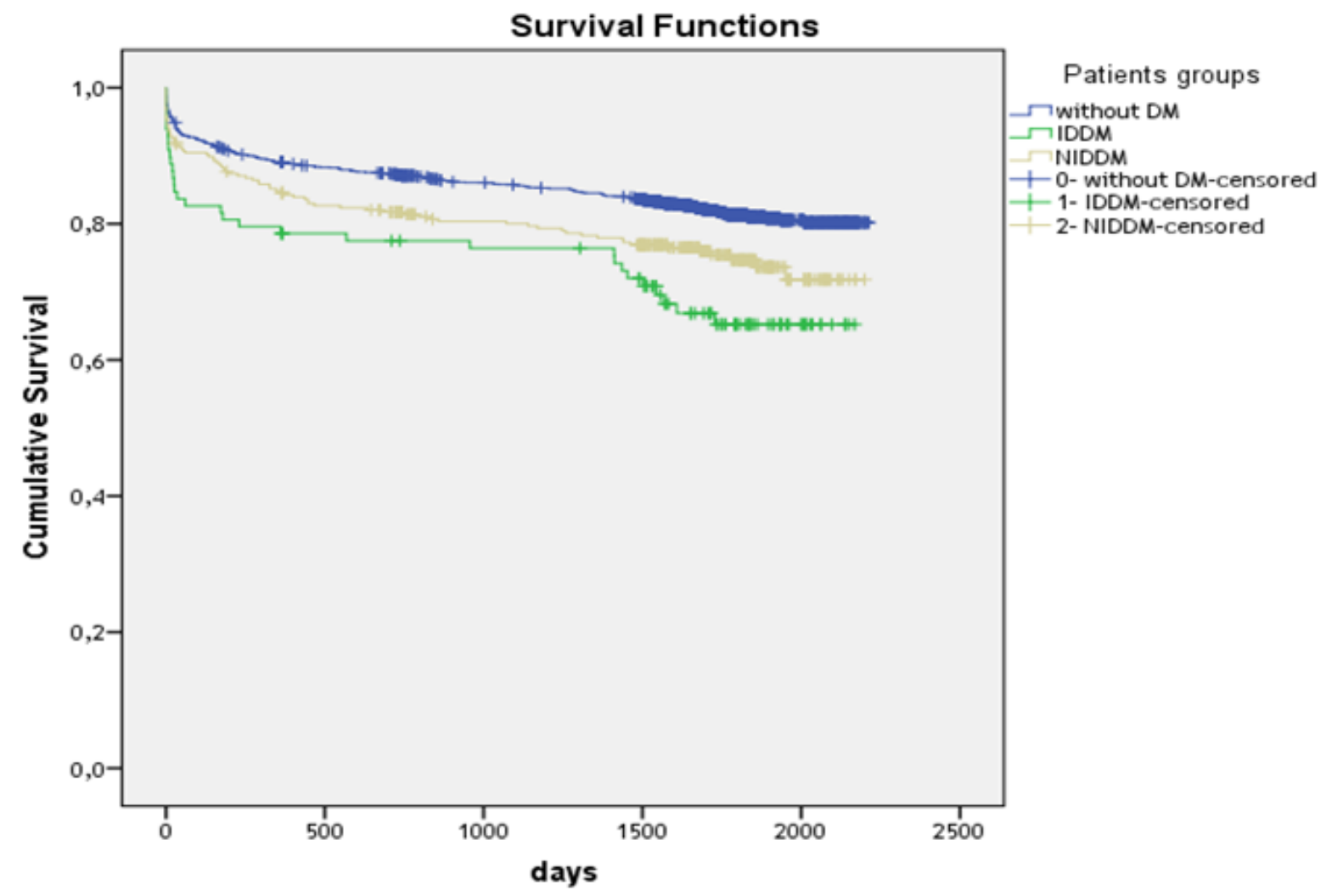

Graph 2. Kaplan-Meier survival curve for all three groups of patients

When adjusted to the baseline characteristics, IDDM was an independent predictor of mortality (HR $=1.58,95 \%$ CI: $1.07-2.32, \mathrm{p}=0.02)$, whereas NIDDM was not $(\mathrm{HR}=1.24,95 \% \mathrm{CI}: 0.95-1.63, \mathrm{p}=0.12)$. Age, previous stroke, previous PCI, the presence of DM, HLP, previous $\mathrm{AF}$, renal failure and $\mathrm{BMI}$ have proved to be independent predictors of five-year mortality.

\section{Discussion}

As it is well known, DM is associated with an increased risk of coronary heart disease and an increased risk of death. Despite advances in the treatment of AMI patients with DM have a significantly worse prognosis and clinical outcome than patients without DM. It is estimated that the number of people with DM will be doubled by 2030 [3]. In our study, $20.26 \%$ of consecutive followed patients with STEMI had DM. Results showed the presence of higher rates of comorbidity in this group of patients. This analysis confirmed that the presence of DM is associated with a higher rate of short-term and long-term mortality in patients with STEMI treated
pPCI $[5,6]$. After performing the stratification of patients with DM in those with IDDM and NIDDM, IDDM was shown to be an independent predictor of mortality after five-year follow-up, when compared with NIDDM. IDDM group had a 1.58 times higher risk (adjusted HR) for mortality during the five-year follow-up compared with patients without DM.

The effect of DM on adverse outcomes in patients with STEMI treated PPCI has been shown in previous studies $[5,6]$. Antoniucci et al. showed that there is a difference in mortality between diabetics and non-diabetics with the highest mortality rate in the group with IDDM [7]. In accordance with the findings of previous studies [8-10], our analysis showed that patients with DM often have more associated risk factors, as well as a higher rate of comorbidities, especially renal failure. Patients with IDDM had the highest rate of other risk factors and comorbidities, which partly explains the highest rate of mortality during long-term follow-up in this group of patients.

Previous researches have identified the following factors associated with poor prognosis in patients with 
STEMI and IDDM: damaged microcirculation, increased risk for atherothrombotic distal embolization, decreased cell viability due to the metabolic disorders caused by diabetic status [11] and less-developed collateral circulation $[12,13]$. In addition to the above mentioned mechanisms, there is debate on the impact of insulin and his adverse effects. On the one side the use of intensive insulin therapy in glycemic control reduces the long-standing risk of cardiovascular disease and all-cause mortality, but on the other side recent studies emerged about the possible undesirable, pro-atherogenic effect of insulin $[14,15]$.

The limitation of our study is the lack of routine measurement of $\mathrm{HbAlc}$ in the blood, which is an indicator of long-term glycemic control parameters, and which has been shown to be associated with the risk of adverse events [3].

\section{References}

1. Electronic database of Institute for Public Health Serbia "Dr Milan Jovanovic Batut". The incidence and mortality of acute coronary syndrome in Serbia. 2013. http://www. batut.org.rs/index/php? contect $=186$.

2. Stone GW, Cox D, Garcia E, Brodie BR, Morice MC, Griffin J et al. Normal flow (TIMI-3) before mechanical reperfusion therapy is an independent determinant of survival in acute myocardial infarction: Analysis from the primary angioplasty in myocardial infarction trials. Circulation 2001; 104 (6):636 641.

3. Hoebers LP, Claessen BE, Woudstra P, DeVries JH, Wykrzykowska JJ, Vis MM et al. Long-term mortality after primary percutaneous coronary intervention for ST-segment elevation myocardial infarction in patients with insulin-treated versus non-insulin-treated diabetes mellitus. Eurointervention 2014 May;10(1):90-6.

4. Kushner FG, Hand M, Smith SC Jr, King SB 3rd, Anderson JL, Antman EM, et al. 2009 focused updates: ACC/AHA guidelines for the management of patients with ST-elevation myocardial infarction (updating the 2004 guideline and 2007 focused update) and ACC/AHA/SCAI guidelines on percutaneous coronary intervention (updating the 2005 guideline and 2007 focused update) a report of the American College of Cardiology Foundation/American Heart Association Task Force on Practice Guidelines. J Am Coll Cardiol 2009;54:2205-41.

5. van der Schaaf RJ, Henriques JP, Wiersma JJ, Koch KT, Baan J Jr, Mulder KJ, et al. Primary percutaneous coronary intervention for patients with acute ST elevation myocardial infarction with and without diabetes mellitus. Heart 2006;92:117-8.
6. Harjai KJ, Stone GW, Boura J, Mattos L, Chandra H, Cox $\mathrm{D}$, et al. Comparison of outcomes of diabetic and nondiabetic patients undergoing primary angioplasty for acute myocardial infarction. Am J Cardiol. 2003;91:1041-5.

7. Antoniucci D, Valenti R, Migliorini A, Parodi G, Moschi $G$, Memisha $G$ et al. Impact of insulin-requiring diabetes mellitus on effectiveness of reperfusion and outcome of patients undergoing primary percutaneous coronary intervention for acute myocardial infarction. Am J Cardiol 2004;93:1170-2.

8. Granger CB, Califf RM, Young S, Candela R, Samaha J, Worley S, et al. Outcome of patients with diabetes mellitus and acute myocardial infarction treated with thrombolytic agents. The Thrombolysis and Angioplasty in Myocardial Infarction (TAMI) Study Group. J Am Coll Cardiol 1993;21:920-925.

9. Mak KH, Moliterno DJ, Granger CB, Miller DP, White HD, Wilcox RG, et al. Influence of diabetes mellitus on clinical outcome in the thrombolytic era of acute myocardial infarction. GUSTO-I Investigators. Global Utilization of Streptokinase and Tissue Plasminogen Activator for Occluded Coronary Arteries. J Am Coll Cardiol 1997;30:171179.

10. Waldecker B, Waas W, Haberbosch W, Voss R, SteenMüller MK, Hiddessen A, et al. Type 2 diabetes and acute myocardial infarction. Angiographic findings and results of an invasive therapeutic approach in type 2 diabetic versus nondiabetic patients. Diabetes Care 1999;22:18321838.

11. Nahser PJ J, Brown RE, Oskarsson H, Winniford MD, Rossen JD. Maximal coronary flow reserve and metabolic coronary vasodilation in patients with diabetes mellitus. Circulation 1995;91:635-40.

12. Santoro GM, Valenti R, Buonamici P, Bolognese L, Cerisano G, Moschi G, et al. Relation between ST-segment changes and myocardial perfusion evaluated by myocardial contrast echocardiography in patients with acute myocardial infarction treated with direct angioplasty. Am J Cardiol 1998;82:932-7.

13. Abaci A, Oguzhan A, Kahraman S, Eryol NK, Unal S, Arinç H, et al. Effect of diabetes mellitus on formation of coronary collateral vessels. Circulation 1999;99:2239-42.

14. Holman RR, Paul SK, Bethel MA, Matthews DR, Neil HA. 10-year follow-up of intensive glucose control in type 2 diabetes. N Engl J Med 2008;359:1577-89.

15. Rensing KL, Reuwer AQ, Arsenault BJ, von der Thüsen JH, Hoekstra JB, Kastelein JJ, et al. Reducing cardiovascular disease risk in patients with type 2 diabetes and concomitant macrovascular disease: can insulin be too much of a good thing? Diabetes Obes Metab 2011;13:1073-87. 